\title{
Soil warming accelerates decomposition of fine woody debris
}

\author{
Minda R. Berbeco • Jerry M. Melillo • \\ Colin M. Orians
}

Received: 26 July 2011 / Accepted: 9 January 2012 / Published online: 23 February 2012

(C) The Author(s) 2012. This article is published with open access at Springerlink.com

\begin{abstract}
Background and aims Soil warming from global climate change could increase decomposition of fine woody debris (FWD), but debris size and quality may mitigate this effect. The goal of this study was to investigate the effect of soil warming on decomposition of fine woody debris of differing size and quality.

Methods We placed FWD of two size classes $(2 \times 20 \mathrm{~cm}$ and $4 \times 40 \mathrm{~cm}$ ) and four species (Acer saccharum, Betula lenta, Quercus rubra and Tsuga canadensis) in a soil warming and ambient area at Harvard Forest in central Massachusetts. We collected the debris from each area over two years and measured mass loss and lignin concentration.

Results Warming increased mass loss for all species and size classes (by as much as $30 \%$ ), but larger debris and debris with higher initial lignin content decomposed slower than smaller debris and debris with lower
\end{abstract}

Responsible Editor: Alfonso Escudero.

M. R. Berbeco $(\bowtie)$

Land, Air and Water Resources, University of California,

Davis, CA 95616, USA

e-mail: mberbeco@gmail.com

J. M. Melillo

Marine Biological Laboratory, Ecosystems Center,

Woods Hole, MA 02543, USA

C. M. Orians

Department of Biology, Tufts University,

Medford, MA 02155, USA initial lignin content. Lignin degradation did not follow the same trends as mass loss. Lignin loss from the most lignin-rich species, T. canadensis, was the highest despite the fact that it lost mass the slowest.

Conclusions Our results suggest that soil warming will increase decomposition of FWD in temperate forests. It is imperative that future models and policy efforts account for this potential shift in the carbon storage pool.

Keywords Woody debris · Lignin · Decomposition · Soil warming $\cdot$ Climate change

\section{Introduction}

The stability of the fine woody debris (FWD) carbon pool is at risk from global climate change. Currently, under undisturbed conditions, woody debris decomposition contributes minimally to total stand respiration in temperate New England forests (Liu et al. 2006), however this could change with global climate change as warmer temperatures have been shown to increase decomposition in temperate forests (Moore et al. 1999; Mackensen et al. 2003). In addition, insect-driven tree mortality may increase the size of the FWD pool (Orwig and Foster 1998), making carbon storage in this pool even more valuable. The magnitude of a change in decomposition due to warmer temperatures may be mitigated by quality, as determined by the biochemical complexity of the debris (Aber 
and Melillo 2001), and the size of FWD, as both have been shown to slow decomposition. While some studies have investigated the effect of debris quality and size on decomposition of FWD (Vávřová et al. 2009; Fasth et al. 2011; Tuomi et al. 2011), few have simultaneously examined how these factors will interact with warming in an experimental field setting. As a result, it is not clear how much warming will speed decomposition from this carbon pool or what factors could mitigate this mass loss.

Debris quality is important to our understanding of FWD decomposition (Cornelissen 1996; Vávřová et al. 2009; Yang et al. 2010). Characterized from the microbe's perspective, litter quality is defined by the accessibility of carbon molecules (Couteaux et al. 1995). Plant materials with more labile carbon are easier to break down and therefore are considered higher quality, while materials with more recalcitrant carbon are considered lower quality (Aber and Melillo 2001; Chapin et al. 2002). Complex carbon molecules such as lignins decrease debris quality and therefore can slow decomposition, while nitrogen increases quality and therefore can increase decomposition (Swift et al. 1979). These variables vary predictability between species and as a result, species are often used as a surrogate for litter quality. Although some studies have found a difference in species decomposition rates (Fasth et al. 2011) and others have connected those differences to lignin concentration (Tuomi et al. 2011), still others found an effect of species only in later stages of decomposition (Liu et al. 2006). As a result, it is imperative that we complete field experiments to see if species and lignin concentration can be used as predictors of fine woody debris decomposition under a warming scenario.

Debris size is another factor with potential effects on decomposition. Aside from obvious differences in mass, and therefore time to complete decomposition, size can act as a buffer to extreme temperature and moisture changes, as larger debris will be able to maintain higher moisture levels longer. Larger debris may also reduce access to decomposers through a low surface to volume ratio and a lower rate of gas and water exchange per unit volume (Mackensen et al. 2003). Indeed, several studies on FWD have found an inverse relationship between debris diameter and decomposition down to $3 \mathrm{~cm}$ in diameter (Tuomi et al. 2011) and less (Muller-Using and Bartsch 2009). Vávřová et al. (2009) attributed this relationship to higher amounts of labile, soluble components in smaller debris, making it easier to decompose. The interaction of quality and debris size may be more complex though, as Fasth et al. (2011) found that certain species with decay resistant heartwood had an inverted size effect (decomposition rate increased with size). Erickson et al. (1985) found a similar relationship between debris size and decomposition in logging residues under $12 \mathrm{~cm}$ diameter. However, they attributed the increase in decomposition with debris size to debris moisture rather than quality, as the smaller debris had a lower moisture content in the dry season potentially slowing decomposition. In light of these many studies, debris size could be a correlate for moisture content, debris quality or microbial access. As each of these factors could interact with warming, it is important that they are taken into account when considering decomposition under future environmental conditions.

Though the FWD pool is only $2 \%$ of total forest carbon storage (Currie and Nadelhoffer 2002; Bradford et al. 2010), storage in this pool is very stable (Mattson et al. 1987). In addition, the size of this pool can be increased by extreme weather events (Fasth et al. 2011) or insect invasion (Orwig and Foster 1998) that result in branch fall and tree mortality. If decomposition of FWD is increased by warming, significant amounts of additional carbon may be released into the atmosphere. Such a pulse of additional carbon entering the atmosphere has consequences for the larger global carbon cycle.

In this study, we examined the effect of soil warming on woody debris decomposition as a function of debris quality and size. We hypothesized that decomposition would increase in response to warming, but that debris quality would influence decomposition, with higher lignin debris decomposing slower under ambient and warmed conditions. We also predicted that smaller debris would decompose faster than larger debris, under both warming and ambient conditions.

\section{Materials and methods}

\section{Site information}

Barre Woods is located in the Harvard Forest Research Station in Central Massachusetts (Melillo et al. 2010). The stand is an even-aged, mixed-hardwood forest dominated by Quercus rubra with lesser components of Acer saccharum, Betula lenta and Tsuga canadensis occurring on Gloucester stony loam soil. Historical 
documents suggest that in earlier years it was pastureland which was growing back naturally with a single strong hurricane disturbance in 1938. The climate in this region is cool, temperate and humid, with a mean annual air temperate of $8.5^{\circ} \mathrm{C}\left(-6^{\circ} \mathrm{C}\right.$ in winter and $20^{\circ} \mathrm{C}$ in the summer). Annual precipitation is $108 \mathrm{~cm}$, distributed evenly throughout the year.

Soil warming treatment

In the Summer of 2001, $5.47 \mathrm{~km}$ of heating cables were buried at a depth of $10 \mathrm{~cm}, 20 \mathrm{~cm}$ apart across a $30 \times 30 \mathrm{~m}$ area. A $30 \times 30 \mathrm{~m}$ ambient area was delineated approximately $5 \mathrm{ft}$ from the warming area. Baseline measurements of soil moisture and temperature were taken in 2002 showing no difference between the two areas (Melillo et al. 2010). Cables were not buried in the ambient area, because previous research found no temperature, moisture or soil respiration differences between the areas with no cables and those with cables that had never been turned on (Melillo et al. 2002). The power was then turned on in the Spring of 2003. Areas are controlled automatically to keep a $5^{\circ} \mathrm{C}$ differential between the ambient and warming areas at $10 \mathrm{~cm}$ depth.

Moisture level was measured using Time Domain Reflectometer probes set at $5 \mathrm{~cm}$ below the soil surface. In 2007, moisture data were collected every $6 \mathrm{~h}$. From 2008 onward, moisture data were collected every hour. Soil moisture was on average $6 \%$ higher in the ambient area over the heated area for all of the years that our debris was decomposing (unpublished results).

\section{Data collection}

\section{Initial survey of fine woody debris}

In the Fall of 2007, we conducted an initial survey for fine woody debris to assess the distribution of debris size and decay class. Due to the small size of the debris and the mix of trees present, we did not determine species. Each treatment area was separated into $10 \times 10 \mathrm{~m}$ areas. Within each smaller area, we used the line-intercept method starting from the center of each area in a random direction to collect information on woody detritus (coarse and fine). The line-intercept method is a good approach to accurately quantify FWD over large areas (Brown 1971) and has been successfully used in Harvard Forest woody debris studies in the past (Currie and Nadelhoffer 2002). Decay class was split into 3 groups based on the work of Currie and Nadelhoffer (2002): sound (no evidence of decay), intermediate (missing some bark, density is soft to the touch, wood is missing) and rotten (wood is rotten the whole way through).

\section{Soil warming decomposition experiment}

In the Fall of 2007, live saplings of 4 species were cut to serve as experimental fine woody debris: Acer saccharum, Betula lenta, Quercus rubra and Tsuga canadensis. These four species were chosen due to their forest abundance and difference in quality. From the survey earlier in the Summer, it was determined that the majority of downed woody debris within the site was less than $5 \mathrm{~cm}$ in diameter. Since Harmon and Sexton (1996) recommend having the length ten times longer than the diameter, as the radial colonization rate by decomposers is $10 \%$ of the longitudinal rate, we cut the fresh wood into two size classes keeping the ratio of diameter to length constant: $2 \mathrm{~cm}$ diameter by $20 \mathrm{~cm}$ long and $4 \mathrm{~cm}$ diameter by $40 \mathrm{~cm}$ long. Due to the size of the saplings available in the forest, pieces of wood were cut from the bole at approximately $1-2 \mathrm{ft}$ from the ground for the $4 \mathrm{~cm}$ diameter pieces and from branches for the $2 \mathrm{~cm}$ diameter pieces. We cut an additional $2.54 \mathrm{~cm}$ piece of debris from each tree to do an initial analysis of moisture and used a subset of those pieces for lignin analysis. Debris was left with bark still intact to accurately represent what we observed from our initial survey of woody debris. We weighed the debris and placed it in debris bags with a $5 \mathrm{~mm}$ mesh to allow decomposers access. Two pieces of debris (one of each size) from the same species were put into individual bags. The bags were then anchored under the leaf litter in subplots within each treatment area.

We divided each $30 \times 30 \mathrm{~m}$ treatment area into nine $10 \times 10 \mathrm{~m}$ subplots. Within each of the nine subplots two $1 \times 1 \mathrm{~m}$ mini-plots were randomly located and served as the locations for this experiment. The experiment was set up in the Fall of 2007. In the two subsequent Falls, we removed 18 debris bags per species from each treatment area for a total of 288 pieces of woody debris ( 4 species $* 2$ size classes $* 2$ treatment areas $* 9$ subplots $* 2$ mini-plots $=288$ ). From the collected debris we determined mass loss and moisture content. 
To evaluate mass loss we measured debris before and after being put in the field. Since the woody debris was placed out as fresh wood, moisture concentration was calculated by weighing the wet $2.54 \mathrm{~cm}$ subsamples, drying them in an oven at $70^{\circ} \mathrm{C}$ until the weight did not change (approximately $48 \mathrm{~h}$ ) and then weighing them again. Debris moisture was on average between $28-48 \%$ moisture, with $T$. canandensis having the greatest moisture and $B$. lenta having the least. Due to the amount of debris needed for this study and the desire to have the same time of death, we chose to create our own debris from fresh saplings. If decomposition was increased due to the fresh debris having higher moisture or more labile constituents than typical FWD, it would become apparent when comparing the decay constants from this study to other studies that used dried and downed FWD (see discussion).

Using mass loss we calculated the decay constants for each species and size under warming and ambient conditions using the following single exponential model which assumes that decomposition rate is proportional to the amount of mass left (Olson 1963):

$\mathrm{k}=(\ln \mathrm{M} 0-\ln \mathrm{Mt}) / t$

Where $\mathrm{k}$ is the decay constant, $\mathrm{M}_{\mathrm{t}}$ is mass at time $\mathrm{t}, \mathrm{M}_{0}$ is mass at time 0 . To look at estimated time to decompose $95 \%\left(t_{0.95}\right)$ of matter we used the equation:

$\mathrm{t}_{0.95}=-\ln (0.05) / \mathrm{k}$

\section{Lignin analysis}

Lignin was analyzed from samples ground to $1 \mathrm{~mm}$ using a Thomas Model 4 Wiley Mill and thoroughly mixed. All samples from each year of decomposition (year 1 and 2) were analyzed for lignin, but a subsample of 10 samples per treatment, per size class were used for initial lignin concentration (year 0). Lignin was analyzed using the acetyl bromide method (developed from Johnson et al. 1961), using species-specific wood standards of known lignin concentration (obtained from Rock River Laboratory, Watertown WI). There are many methods for studying lignin, each with varying ease and flexibility. A study by Fukushima and Hatfield (2004) found that the acetyl bromide method was able to detect the greatest amount of lignin in their small wood forage samples compared to Klason lignin, acid detergent, acid insoluble lignin, or permanganate lignin procedures. Briefly, $20 \mathrm{mg}$ of dried cell-wall extracted sample was combined with $1 \mathrm{ml}$ of $25 \%$ acetyl bromide in glacial acetic acid in Teflon-topped tubes. The tubes were capped and placed in a water bath at $50^{\circ} \mathrm{C}$ for $2 \mathrm{~h}$. The samples were then cooled on ice. We then added $2 \mathrm{ml} 2 \mathrm{M} \mathrm{NaOH}, 2.4 \mathrm{ml}$ acetic acid and $0.350 .5 \mathrm{M}$ hydroxylamine hydrochloride to the samples. Glacial acetic acid was then added to bring the volume up to $10 \mathrm{ml}$. Sample UV absorption was measured against a blank using a spectrophotometer (HP 8452A Diode Array Spectrophotometer) at $280 \mathrm{~nm}$.

\section{Statistical analysis}

We analyzed the effects of warming, debris species and debris size on (1) mass loss and (2) change in lignin concentration using a series of 3-way ANOVAs with treatment, species and size as our main effects. Each year was analyzed separately. A Levine's test failed to find homogeneous variances in many of our data sets and typical transformations did not correct for this. As a result, we rank-transformed all of our data before running the 3-way ANOVA. Rank transformations have been found to be a useful statistical tool that bridge non-parametric and parametric tests when other transformations do not correct violated assumptions of the ANOVA test (Conover and Iman 1981). As we found that size interacted with both temperature and species in our year 1 mass loss data, we broke this data into the two size classes and ran two-way ANOVAs to look more specifically at the effect of size and temperature within each size class. We analyzed our data using SPSS (GradPack v 17.0).

\section{Results}

Initial survey

Total FWD biomass in the initial survey was approximately $2.45 \mathrm{~kg} / \mathrm{m}^{2}$ and $1.63 \mathrm{~kg} / \mathrm{m}^{2}$ in the ambient and soil-warming areas respectively. We found no difference between the two areas for debris size class or decay class. In addition, there was no difference in tree mortality since the experiment started (personal correspondence with Jacqueline Mohan, Spring 2008). In 
both sites, over $95 \%$ of the woody debris was under $5 \mathrm{~cm}$ in diameter and the total number of woody debris sampled was equitable (109 pieces of debris in the ambient area and 108 pieces in the soil warming area). The decay classes for both sites were also very similar, with sound wood being the most prevalent followed by the intermediate decay class and then rotten wood.

Soil warming decomposition experiment

Mass loss

Even though soil moisture was higher in the ambient area (unpublished results), mass loss for all debris was greatest under warming (Fig. 1). In year 1 , size interacted with both temperature and species to significantly influence mass loss (Table 1a; Fig. 1). In the smaller debris class, temperature and species both independently influenced mass loss (Table 2a), with $B$. lenta decomposing the fastest, losing $25 \%$ of its mass. The other species were also strongly affected by temperature, increasing mass loss by approximately $10 \%$ with warming.
In the larger debris class, only temperature had a significant effect on mass loss (Table $2 b$ ).

In year 2, only the main effects of temperature, species and size significantly affected mass loss (Table 1b; Fig. 1). Warming appeared to increase mass loss across all species and the smaller debris decomposed the fastest. In general T. canadensis decomposed slower than the other 3 species, followed by Q. rubra, B. lenta and A. saccharum.

In contrast to decomposition, debris moisture did not differ by treatment in either year. All debris moisture was within the range of $24 \%$ and $47 \%$ in year 1 and $31 \%$ and $55 \%$ in year 2 .

\section{Decay constants}

Similar to our findings for mass loss, we found that the smaller debris and debris with a lower initial lignin content had the higher decay constants under the warming treatment (Table 3a, Fig. 2). Warming shortened the estimated number of years until $95 \%$ of the sample was decayed across all species and size classes, reducing the mean residence time by approximately $30-50 \%$ (Table $3 b$ ).
Fig. 1 Percent mass remaining of small debris $(20 \mathrm{~cm}$ length $\times 2 \mathrm{~cm}$ diameter; squares) and large debris (40 cm length $\times 4 \mathrm{~cm}$ diameter; triangles) of four species: Acer saccharum, Betula lenta, Quercus rubra and Tsuga canadensis over two years of decomposition under either the ambient (black) or the soil warming (gray) treatment ( $n=18$ pieces of debris per size and species in each treatment). Standard error bars are too small to see in most cases
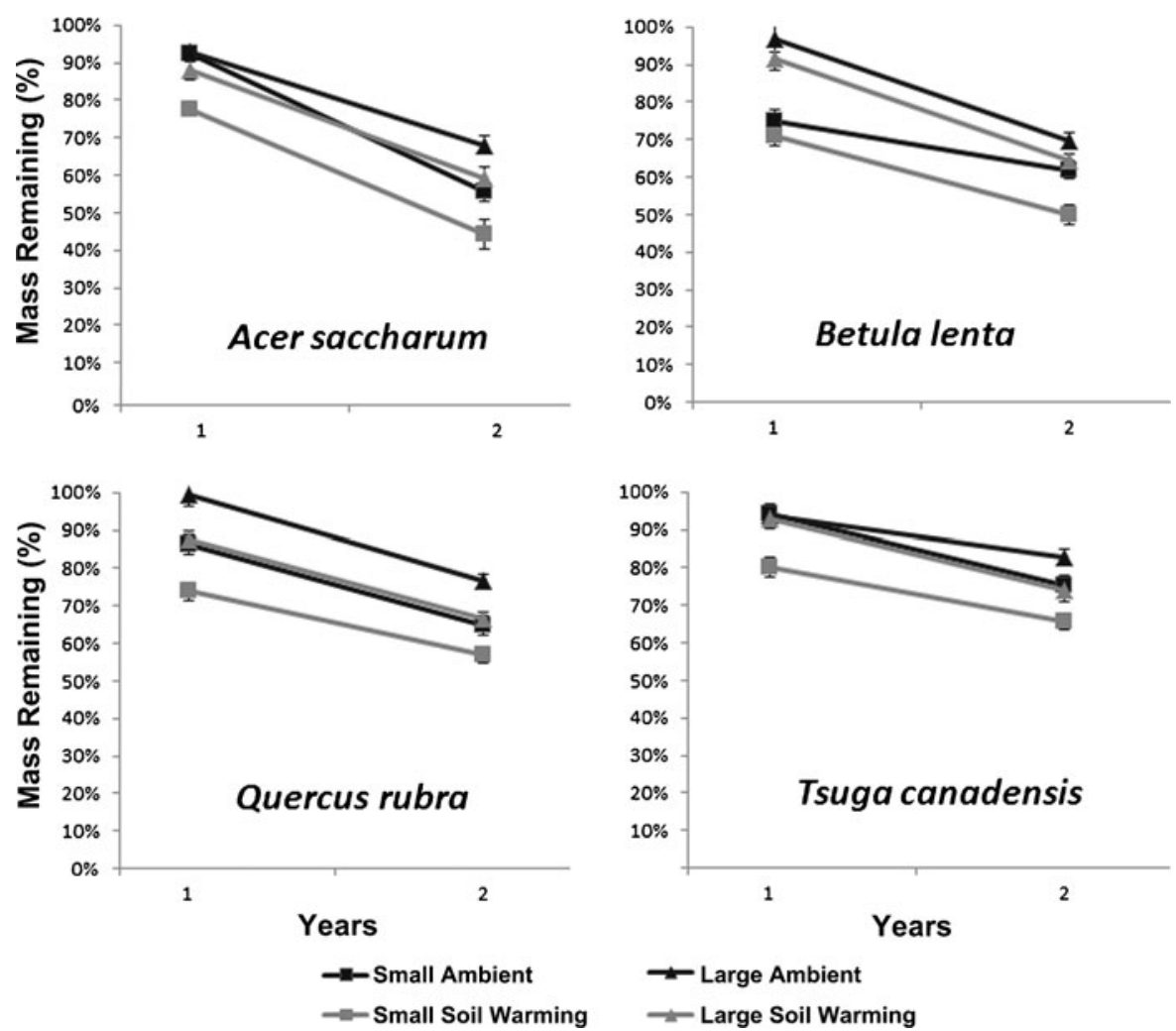
Table 1 Summary of 3-way ANOVAs of woody debris mass loss, for small debris $(20 \mathrm{~cm}$ length $\times 2 \mathrm{~cm}$ diameter $)$ and large debris (40 cm length $\times 4 \mathrm{~cm}$ diameter) across four species: Acer saccharum, Betula lenta, Quercus rubra and Tsuga canadensis after a) one and b) two years under either the ambient or the soil warming treatment $(n=18$ pieces of debris per size and species in each treatment)

\begin{tabular}{|c|c|c|c|}
\hline Source of variation & Df & $F$ & $p$ \\
\hline \multicolumn{4}{|l|}{ a) Year 1} \\
\hline Temperature & 1 & 45.36 & $<0.0001$ \\
\hline Species & 3 & 5.10 & 0.002 \\
\hline Size & 1 & 67.27 & $<0.0001$ \\
\hline Temperature $\times$ Species & 3 & 1.73 & 0.16 \\
\hline Temperature $\times$ Size & 1 & 5.72 & 0.02 \\
\hline Species $\times$ Size & 3 & 5.61 & 0.001 \\
\hline Species $\times$ Size $\times$ Temperature & 3 & 2.15 & 0.09 \\
\hline Error & 272 & & \\
\hline Total & 288 & & \\
\hline \multicolumn{4}{|l|}{ b) Year 2} \\
\hline Temperature & 1 & 55.57 & $<0.0001$ \\
\hline Species & 3 & 35.55 & $<0.0001$ \\
\hline Size & 1 & 74.15 & $<0.0001$ \\
\hline Temperature $\times$ Species & 3 & 0.36 & 0.78 \\
\hline Temperature $\times$ Size & 1 & 0.00 & 0.99 \\
\hline Species $\times$ Size & 3 & 0.46 & 0.71 \\
\hline Species $\times$ Size $\times$ Temperature & 3 & 0.65 & 0.58 \\
\hline Error & 272 & & \\
\hline Total & 288 & & \\
\hline
\end{tabular}

All data was rank transformed before analysis

\section{Lignin analysis}

Temperature had a significant effect on lignin concentration after two years of decomposition, showing an increase in lignin concentration under the warming treatment (Tables 4c and 5 year 2). Meanwhile, species had a significant effect on lignin concentration throughout the experiment (Table 4), but concentration did not remain consistently higher in the same species (Table 5). For example, in year $0, T$. canadensis debris of both size classes had the highest lignin concentration, but by year 2 it had lost the greatest amount of lignin. In the smaller debris, all of the other species increased in lignin concentration. Meanwhile in the larger size class, lignin concentration diverged by year 2 , with $A$. saccharum increasing in lignin concentration and B. lenta and $Q$. rubra staying close to initial levels (Table 5b). Lignin concentration was significantly higher in the larger size class debris before decomposition and after two years (Table 4a and c).

Total lignin content demonstrated a different trend from concentration, as after two years it consistently decreased in all species and treatments (Table 6). The larger T. canadensis debris, which started with the highest lignin content, lost the greatest amount of lignin over the two years of decomposition when compared to the other species and the smaller debris (Table 6b).

\section{Discussion}

We found a large effect of warming, species, and size on decomposition. Combining our initial survey of downed FWD with the experimental warming data suggests that warming could increase decomposition from the FWD pool in our study area between 211 and $456 \mathrm{Cg} / \mathrm{m}^{2}$ over the first two years of decomposition. The calculation assumes a $50 \%$ carbon content in the initial debris (Pettersen 1984). This range was dependent on species

Table 2 Summary of 2-way ANOVAs of woody debris mass loss for a) small debris ( $20 \mathrm{~cm}$ length $\times 2 \mathrm{~cm}$ diameter $)$ and $\mathrm{b}$ ) large debris ( $40 \mathrm{~cm}$ length $\times 4 \mathrm{~cm}$ diameter) across four species: Acer saccharum, Betula lenta, Quercus rubra and Tsuga canadensis after one year under either the ambient or the soil warming treatment $(n=18$ pieces of debris per size and species in each treatment)

\begin{tabular}{llll}
\hline Mass loss & & & \\
\hline Source of variation & df & $F$ & $p$ \\
\hline a) Small & & & \\
Temperature & 1 & 49.40 & $<0.0001$ \\
Species & 3 & 12.56 & $<0.0001$ \\
Temperature $\times$ Species & 3 & 2.91 & 0.04 \\
Error & 136 & & \\
Total & 144 & & \\
b) Large & & & 0.005 \\
Temperature & 1 & 8.15 & 0.96 \\
Species & 3 & 0.10 & 0.30 \\
Temperature $\times$ Species & 3 & 1.23 & \\
Error & 136 & & \\
Total & 144 & & \\
\hline
\end{tabular}

All data was rank transformed before analysis 
Table 3 Decomposition patterns for fine woody debris showing a) mean decay constants (year ${ }^{-1}$ ) and b) estimated years to decompose $95 \%$ of debris for small debris (20 cm length $\times 2 \mathrm{~cm}$ diameter) and large debris (40 $\mathrm{cm}$ length $\times$ $4 \mathrm{~cm}$ diameter) across four species: Acer saccharum, Betula lenta, Quercus rubra and Tsuga canadensis and under either the ambient or the soil warming treatment ( $n=18$ pieces of debris per size and species in each treatment)

Standard error is in parenthesis in both tables

\begin{tabular}{llllll}
\hline Species & \multicolumn{2}{l}{ Ambient } & & \multicolumn{2}{l}{ Soil warming } \\
\cline { 2 - 3 } \cline { 5 - 6 } & Large & Small & & Large & Small \\
\hline
\end{tabular}

a) Decay constants

$\begin{array}{lllll}\text { Acer saccharum } & 0.20(0.03) & 0.30(0.04) & 0.27(0.04) & 0.45(0.07) \\ \text { Betula lenta } & 0.18(0.02) & 0.25(0.03) & 0.22(0.02) & 0.36(0.04) \\ \text { Quercus rubra } & 0.14(0.02) & 0.22(0.03) & 0.21(0.02) & 0.29(0.03) \\ \text { Tsuga canadensis } & 0.10(0.02) & 0.14(0.02) & 0.16(0.03) & 0.22(0.02)\end{array}$

b) Estimated years to decompose $95 \%$ of debris.

\begin{tabular}{lllll} 
Acer saccharum & $18(2)$ & $11(1)$ & $13(1)$ & $8(1)$ \\
Betula lenta & $19(2)$ & $14(1)$ & $14(1)$ & $9(1)$ \\
Quercus rubra & $26(3)$ & $16(2)$ & $16(1)$ & $11(1)$ \\
Tsuga canadensis & $41(6)$ & $29(5)$ & $25(4)$ & $15(1)$ \\
\hline
\end{tabular}

and size of debris present, with smaller, higher quality debris contributing a greater amount. This response is large when compared to the effect of warming on other carbon pools. Melillo et al. (2002) found that emissions from soil and roots was $944 \mathrm{gC} / \mathrm{m}^{2}$ over 10 years of warming, with the first 6 years having the highest contribution. The difference in response between FWD and soil may be due to the relative amounts of labile carbon available in each. Though soil holds more carbon in temperate forests, a large proportion is stored in the recalcitrant pool (Gaudinski et al. 2000), while FWD has more labile carbon available. This suggests that even carbon entering soil from FWD, may not be tied into long term storage, but rather be part of the labile pool which again will be respired into the atmosphere. Further research into the recalcitrant nature of this carbon entering the soil pool from FWD is warranted.

Initial survey of fine woody debris

We found $2.45 \mathrm{~kg} / \mathrm{m}^{2}$ and $1.63 \mathrm{~kg} / \mathrm{m}^{2} \mathrm{FWD}$ in the ambient and soil-warming areas respectively. These amounts are slightly higher than in other forest (Lang et al. 1981; McCarthy and Bailey 1994). Currie and Nadelhoffer (2002) found $0.73 \mathrm{~kg} / \mathrm{m}^{2}$ in a different mixed oak forest at Harvard forest and Onega and Eickmeier (1991) found $0.94 \mathrm{~kg} / \mathrm{m}^{2}$ in a Tennessee maple forest. This suggests that the build-up of woody debris on the forest floor is dependent on both location and forest type, making it challenging to devise larger estimations regarding carbon emissions without knowing the debris biomass of a given forest stand. As a result, our predicted emissions within the first two years from the FWD pool may represent an upper end for Eastern US forests.

\section{Soil warming decomposition experiment}

In general, warming significantly increased decomposition of FWD in our study, while species and size appeared to dictate the magnitude of this response. For example, warming shortened the estimated time to 95\% mass loss for the more recalcitrant $T$. canadensis debris of the larger size class by 16 years, while shortening the mean residence time for the other 3 species by only $5-10$ years. This demonstrates that although temperature increases woody debris decomposition, substrate accessibility or quality can dictate the level of the response.

As expected, decomposition was much faster for smaller debris than larger debris under both warming and ambient conditions. Though there are many proposed reasons in the coarse woody debris literature as to why size might influence decomposition, many of those may not pertain to the FWD in our study. For example, Laiho and Prescott (2004) suggested that larger debris could buffer from extreme climate shifts, while Harmon et al. (1986) suggested that quality will be reduced in larger sizes resulting in slower decay in larger debris. In the case of our study, the $2 \mathrm{~cm}$ difference between the diameters of the small and large debris were likely too small to buffer against climate shifts or cause major shifts in quality. Most likely the surface:volume ratio of the debris determined the slower decomposition rates of the larger debris (Mackensen et al. 2003). 
a) Small Debris
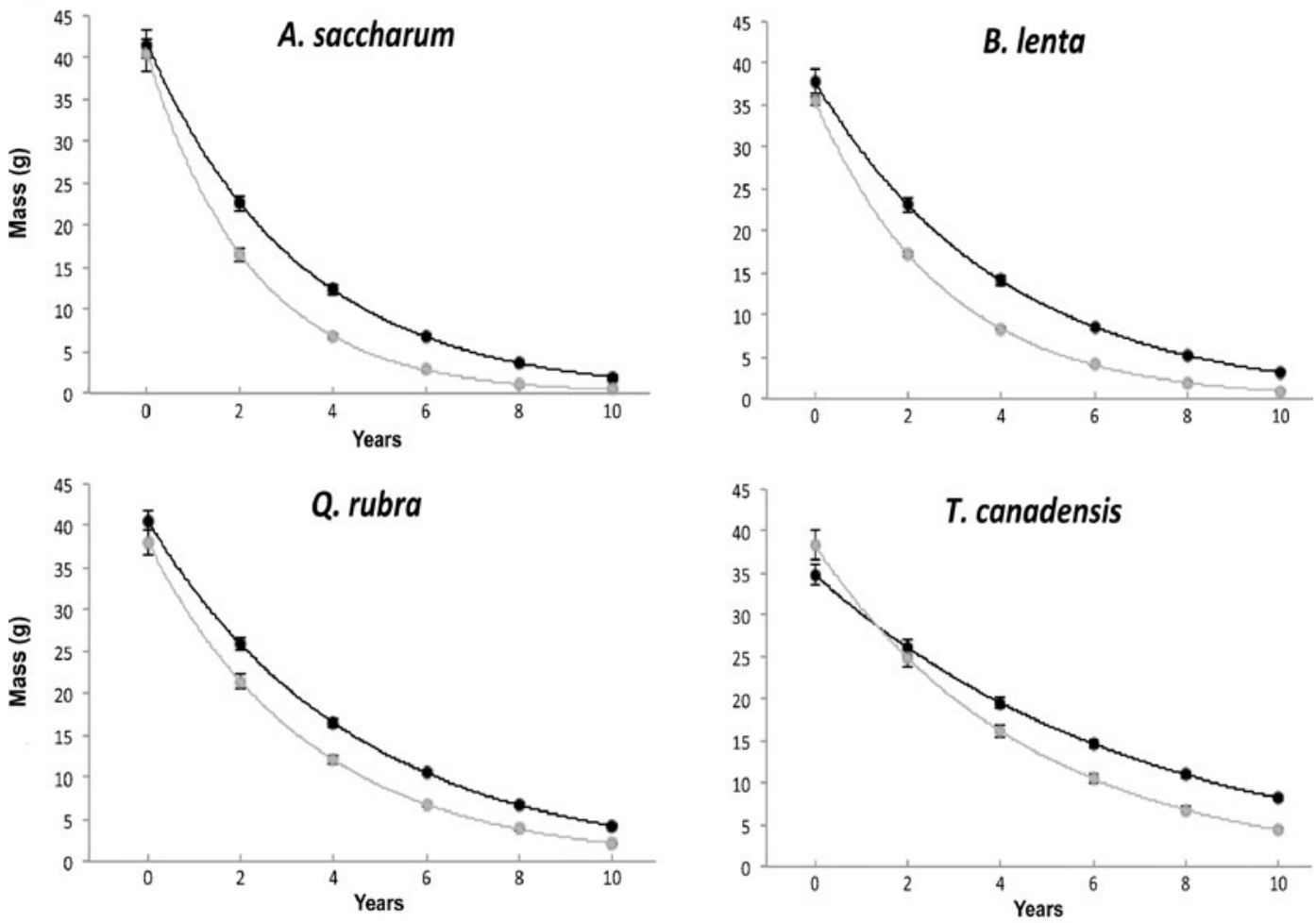

b) Large Debris
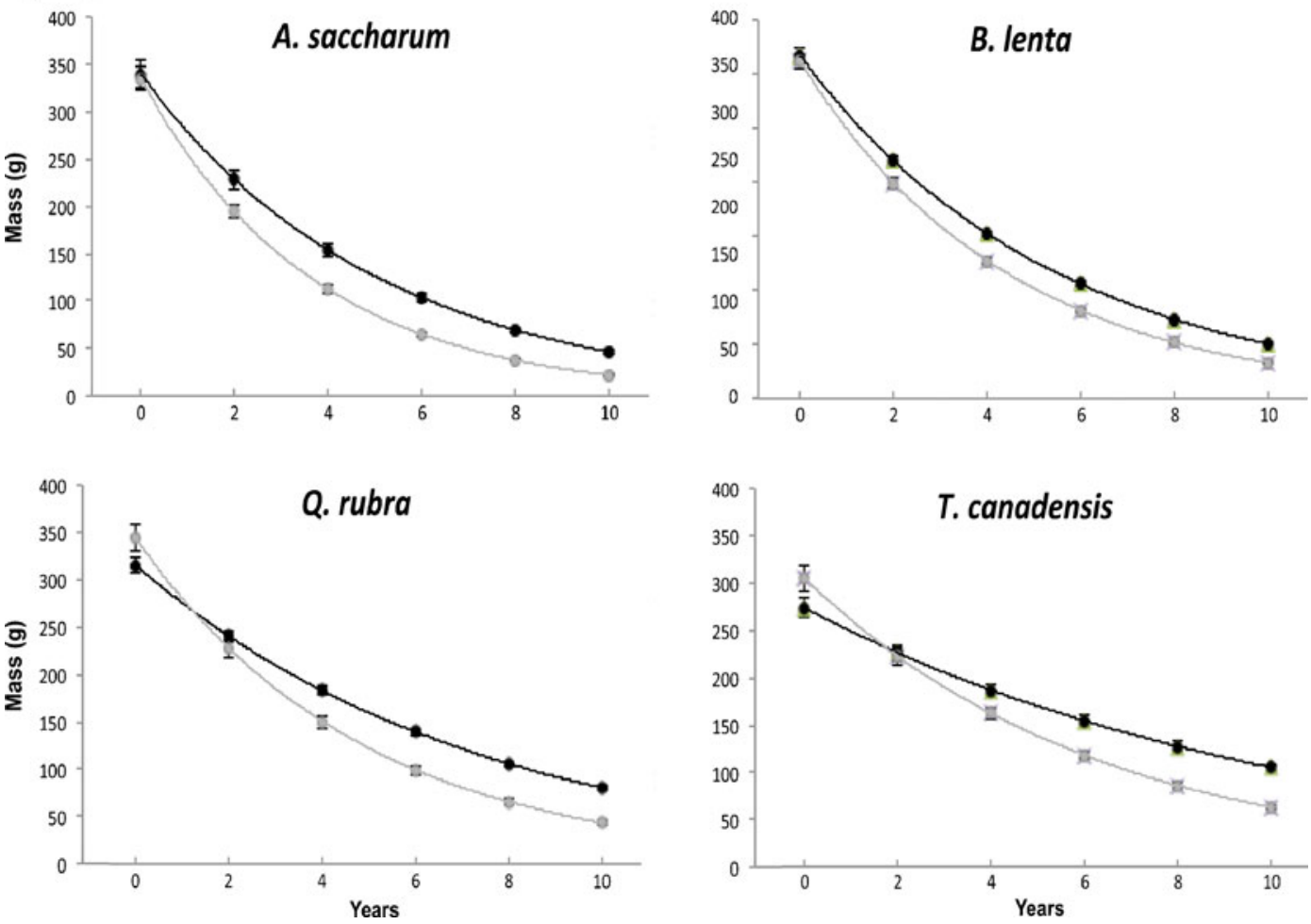
Fig. 2 Exponential decay curves for small $(20 \mathrm{~cm}$ length $\times 2 \mathrm{~cm}$ diameter) and large debris (40 cm length $\times 4 \mathrm{~cm}$ diameter) of four species: Acer saccharum, Betula lenta, Quercus rubra and Tsuga canadensis under either the ambient (black) or the soil warming (gray) treatment ( $n=18$ pieces of debris per size and species in each treatment). Data from the first two years of decomposition was used to predict the following ten years. Standard error bars are too small to see in most cases

Our research, in conjunction with others (Tritton 1980; Mattson et al. 1987; Vávřová et al. 2009), supports the prediction that debris size will influence

Table 4 Summary of a 3-way ANOVA of woody debris lignin concentration for small debris $(20 \mathrm{~cm}$ length $\times 2 \mathrm{~cm}$ diameter) and large debris (40 cm length $\times 4 \mathrm{~cm}$ diameter) across four species: Acer saccharum, Betula lenta, Quercus rubra and Tsuga canadensis under either the ambient or the soil warming treatment

\begin{tabular}{|c|c|c|c|}
\hline Source of variation & $\mathrm{df}$ & $F$ & $P$ \\
\hline \multicolumn{4}{|l|}{ a) Year 0} \\
\hline Species & 3 & 15.32 & $<0.0001$ \\
\hline Size & 1 & 4.60 & 0.035 \\
\hline Species $\times$ Size & 3 & 1.13 & 0.34 \\
\hline Error & 72 & & \\
\hline Total & 80 & & \\
\hline \multicolumn{4}{|l|}{ b) Year 1} \\
\hline Temperature & 1 & 2.94 & 0.09 \\
\hline Species & 3 & 35.46 & $<0.0001$ \\
\hline Size & 1 & 0.003 & 0.95 \\
\hline Temperature $\times$ Species & 3 & 1.86 & 0.14 \\
\hline Temperature $\times$ Size & 1 & 0.001 & 0.98 \\
\hline Species $\times$ Size & 3 & 0.59 & 0.62 \\
\hline Species $\times$ Size $\times$ Temperature & 3 & 0.04 & 0.99 \\
\hline Error & 272 & & \\
\hline Total & 288 & & \\
\hline \multicolumn{4}{|l|}{ c) Year 2} \\
\hline Temperature & 1 & 11.79 & 0.001 \\
\hline Species & 3 & 24.98 & $<0.0001$ \\
\hline Size & 1 & 25.45 & $<0.0001$ \\
\hline Temperature $\times$ Species & 3 & 0.93 & 0.43 \\
\hline Temperature $\times$ Size & 1 & 1.91 & 0.17 \\
\hline Species $\times$ Size & 3 & 0.96 & 0.41 \\
\hline Species $\times$ Size $\times$ Temperature & 3 & 0.66 & 0.58 \\
\hline Error & 272 & & \\
\hline Total & 288 & & \\
\hline
\end{tabular}

Samples were measured a) initially and then after b) one and c) two years of decomposition in the field ( $n=18$ pieces of debris per size and species in each treatment). All data was rank transformed before analysis decomposition under ambient conditions, with smaller debris decomposing faster than larger debris. Though our analysis fits the literature well, our decay constant and the estimated time of $95 \%$ mass loss was based on only 2 years of data. FWD decomposition can be slowest within the first 2 years (Fasth et al. 2011), suggesting that our estimated times to $95 \%$ mass loss may underestimate the amount of time it will take for the debris to decompose. Regardless of the absolute time to $95 \%$ mass loss, our results clearly show that warming will expedite this process.

In our study, the relationship between mass loss and initial lignin concentration might erroneously suggest lignin is slowing decomposition, thereby accounting for the lignin-rich T. canadensis decomposing slower than all other species. However a closer look at lignin concentration over time shows that lignin in the larger T. canadensis debris was consumed in higher proportion than in the other species. Perhaps other factors related to the differing wood structure (Scheffer and Cowling 1966) were determining the slow decay rate of T. canadensis or perhaps initial lignin content was determining long-term decomposition rates by dictating the community that would initially colonize the debris.

Several studies have found that the microbial community present determines the type of carbon being consumed (Worrall et al. 1997; Fukusawa et al. 2011). While brown-rot fungi will consume cellulose and hemicellulose over lignin (Preston et al. 1998), white-rot fungi will decompose all three (Kirk and Highley 1973; Okino et al. 2008) occasionally consuming lignin before other carbon constituents (Blanchette 1984). Given these previous findings, the divergent lignin concentrations in our decomposing debris may suggest that $T$. canadensis debris were colonized by white-rot fungi, while the other wood species was colonized by brown-rot fungi. This deserves further study.

Several studies found that both temperature and moisture availability (through internal wood moisture content or precipitation) increased decomposition (Wang et al. 2002; Garrett et al. 2007; Vávřová et al. 2009; Wu et al. 2010). Specifically, moisture levels below 30\% can hinder fungal growth (Kaarik 1974). After one year of decomposition, we did find that some of our larger debris moisture content was below this $30 \%$ threshold, however this did not appear to differ by treatment. By year 2, all of the debris moisture was above this threshold. Moreover, the soil moisture 
Table 5 Lignin concentration $(\mathrm{mg} / \mathrm{g})$ for a) small $(20 \mathrm{~cm}$ length $\times 2 \mathrm{~cm}$ diameter) and b) larger (40 cm length $\times 4 \mathrm{~cm}$ diameter) debris from before decomposition (subsamples analyzed for year 0 ) through 2 years of decomposition (year 1 and
2) across four species: Acer saccharum, Betula lenta, Quercus rubra and Tsuga canadensis under either the ambient or the soil warming treatment $(n=18$ pieces of debris per size and species in each treatment)

\begin{tabular}{|c|c|c|c|c|c|}
\hline \multirow[t]{2}{*}{ Species } & \multirow[t]{2}{*}{ Year 0} & \multicolumn{2}{|l|}{ Year 1} & \multicolumn{2}{|l|}{ Year 2} \\
\hline & & Ambient & Soil warming & Ambient & Soil warming \\
\hline \multicolumn{6}{|l|}{ a) Small debris } \\
\hline Acer saccharum & $177(14.80)$ & $255(16.30)$ & $242(10.95)$ & $289(23.11)$ & 365 (23.97) \\
\hline Betula lenta & $195(13.14)$ & $232(13.40)$ & $215(23.70)$ & $243(16.38)$ & 305 (20.97) \\
\hline Quercus rubra & 217 (18.79) & 165 (11.55) & $186(5.63)$ & $223(12.54)$ & $233(10.84)$ \\
\hline Tsuga canadensis & $279(19.14)$ & $268(15.96)$ & $247(17.91)$ & 219 (11.17) & $245(15.20)$ \\
\hline \multicolumn{6}{|l|}{ b) Large debris } \\
\hline Acer saccharum & $201(13.63)$ & $260(11.37)$ & $252(12.65)$ & $257(12.65)$ & $261(14.11)$ \\
\hline Betula lenta & $232(13.21)$ & $214(8.87)$ & 205 (19.09) & $230(16.76)$ & $257(17.01)$ \\
\hline Quercus rubra & $205(9.63)$ & $174(8.58)$ & $184(9.41)$ & $199(13.45)$ & $199(7.40)$ \\
\hline Tsuga canadensis & $334(21.25)$ & $277(15.41)$ & $265(23.94)$ & $174(13.66)$ & 198 (10.67) \\
\hline
\end{tabular}

Standard error is in parenthesis

was higher in the ambient area than the warming area, which would lead to the prediction that decomposition would be higher in the ambient area. This was not the case, leading us to believe that warming, not moisture, was driving increased decomposition, but that the effect of temperature could be greater with increased moisture conditions. It should be noted that debris moisture can vary significantly throughout the year, particularly in response to precipitation events. We only took measures

Table 6 Lignin content in grams for a) small (20 cm length $\times$ $2 \mathrm{~cm}$ diameter) and b) larger (40 cm length $\times 4 \mathrm{~cm}$ diameter) debris from before decomposition (subsamples analyzed for year 0 ) through 2 years of decomposition (year 1 and 2) across of debris moisture once a year when we pulled our samples from the field. Therefore we must be cautious when interpreting our findings to not exclude the possibility that debris moisture may have still contributed to the increased decomposition of the debris in the soil-warming area.

In our study, we used live tissue at the start of our experiment rather than dead tissue. This was due to the desire to have an extensive amount of FWD available

four species: Acer saccharum, Betula lenta, Quercus rubra and Tsuga canadensis under either the ambient or the soil warming treatment $(n=18$ pieces of debris per size and species in each treatment)

\begin{tabular}{|c|c|c|c|c|c|}
\hline \multirow[t]{2}{*}{ Species } & \multirow[t]{2}{*}{ Year 0} & \multicolumn{2}{|l|}{ Year 1} & \multicolumn{2}{|l|}{ Year 2} \\
\hline & & Ambient & Soil warming & Ambient & Soil warming \\
\hline \multicolumn{6}{|l|}{ a) Small debris } \\
\hline Acer saccharum & $6.71(0.22)$ & $7.81(0.64)$ & $7.19(0.55)$ & $6.25(0.38)$ & $6.41(0.72)$ \\
\hline Betula lenta & $7.22(0.19)$ & $5.95(0.39)$ & $5.69(0.60)$ & $5.55(0.42)$ & $5.26(0.36)$ \\
\hline Quercus rubra & $8.51(0.17)$ & $5.85(0.47)$ & $5.85(0.32)$ & $5.73(0.32)$ & $4.95(0.23)$ \\
\hline Tsuga canadensis & $8.85(0.33)$ & $7.22(0.57)$ & $6.87(0.59)$ & $5.88(0.44)$ & $6.16(0.49)$ \\
\hline \multicolumn{6}{|l|}{ b) Large debris } \\
\hline Acer saccharum & $67.77(1.94)$ & $71.53(3.42)$ & $82.13(5.83)$ & $58.95(4.42)$ & $51.49(3.93)$ \\
\hline Betula lenta & $65.51(2.31)$ & $61.08(3.41)$ & $52.24(4.15)$ & $49.82(3.54)$ & $51.66(4.37)$ \\
\hline Quercus rubra & $78.29(1.01)$ & $64.56(4.06)$ & $58.10(3.25)$ & $47.98(3.88)$ & $44.90(2.21)$ \\
\hline Tsuga canadensis & $94.40(2.92)$ & $76.22(5.49)$ & $65.11(5.82)$ & $38.78(2.63)$ & $43.48(2.54)$ \\
\hline
\end{tabular}

Standard error is in parenthesis 
to us, while knowing the time since death for all of the debris to ensure that some debris did not start decomposing prior to our experiment. Thus, the FWD in this study had a higher moisture content and more labile components (Pettersen 1984) at the start of our experiment than if the branches or trees had died naturally, dried out and fallen to the ground. Therefore, the rates of decomposition could be faster in our study than what would occur in the latter scenario. Interestingly, our decay constants for the control plot are similar to other studies that utilized dead tissue (Tritton 1980; Mattson et al. 1987), suggesting that the use of live tissue did not bias our decomposition results.

\section{Conclusions}

Barford et al. (2001) suggested that prior disturbance and management of New England forests have made them ideal for carbon management, but our research suggests that an increase in temperature may change the potential for carbon storage in these forests. Our findings of a $20-30 \%$ increase in FWD decomposition with soil warming matches a study by Melillo et al. (Melillo et al. 2002) on the effect of warming on the decomposition of soil organic matter. However in the Melillo study, the stimulatory effects of warming decreased after 6 years. They attributed this to the consumption of a labile soil carbon pool that was not immediately replenished by detrital inputs. The woody debris pool however has consistent and regular new inputs over time, suggesting that there may not be a leveling off of emissions from this pool as with soil. These findings are important for future carbon models, because of the increased speed in which organic matter will enter the soil carbon pool and the atmosphere.

Overall, our study demonstrates that soil warming will increase decomposition of FWD in temperate forests. Although the decay rate may be mitigated by the debris species and size, the exact mechanisms driving the variation in woody debris decomposition are still not clear. More research into the microbial communities and the type of carbon consumed is required to understand how warming may interact with debris quality to alter decomposition patterns. This increase in decomposition due to warming and the mechanisms that drive them needs to be included in future climate models (Ostle et al. 2009) as the temperate forest woody debris carbon pool could shift from a sink to a source in the next 100 years (Yin 1999).
Acknowledgements The authors would like to thank Will Fertman, Colleen Butler, Coco Gomez, Alex Thorn, Liza McFarland, Tim Korpita, Leszek Bledzki, GWIS, Michael Reed, Adrien Finzi, George Ellmore, Sarah Butler, Tufts Biology Department and Graduate School, and Harvard Forest LTER.

Open Access This article is distributed under the terms of the Creative Commons Attribution License which permits any use, distribution, and reproduction in any medium, provided the original author(s) and the source are credited.

\section{References}

Aber JD, Melillo JM (2001) Terrestrial ecosystems. Saunders College Publishing, Philadelphia

Barford CC, Wofsy SC, Goulden ML, Munger JW, Pyle EH, Urbanski SP, Hutyra L, Saleska SR, Fitzjarrald D, Moore K (2001) Factors controlling long- and short-term sequestration of atmospheric $\mathrm{CO} 2$ in a mid-latitude forest. Science 294(5547):1688-1691. doi:10.1126/science.1062962

Blanchette RA (1984) Screening wood decayed by white rot fungi for preferential lignin degradation. Appl Environ Microbiol 48(3):647-653

Bradford JB, Weishampel P, Smith ML, Kolka R, Birdsey RA, Ollinger SV, Ryan MG (2010) Carbon pools and fluxes in small temperate forest landscapes: variability and implications for sampling design. For Ecol Manage 259(7):12451254. doi:10.1016/j.foreco.2009.04.009

Brown JK (1971) A planar intersect method for sampling fuel volume and surface area. For Sci 17(1):96-102

Chapin FS, Matson PA, Mooney HA (2002) Principles of terrestrial ecosystem ecology. Springer-Science, NY

Conover WJ, Iman RL (1981) Rank transformations as a bridge between parametric and nonparametric statistics. Am Stat 35(3):124-129. doi:10.2307/2683975

Cornelissen JHC (1996) An experimental comparison of leaf decomposition rates in a wide range of temperate plant species and types. J Ecol 84(4):573-582. doi:10.2307/ 2261479

Couteaux MM, Bottner P, Berg B (1995) Litter decomposition, climate and litter quality. Trends Ecol Evol 10(2):63-66. doi:10.1016/s0169-5347(00)88978-8

Currie WS, Nadelhoffer KJ (2002) The imprint of land-use history: patterns of carbon and nitrogen in downed woody debris at the Harvard Forest. Ecosystems 5(5):446-460. doi:10.1007/s10021-002-1153-x

Erickson HE, Edmonds RL, Peterson CE (1985) Decomposition of logging residues in Douglas-Fir, Western Hemlock, Pacific Silver Fir, and Ponderosa Pine Ecosystems. Can J For ResRev Can Rech For 15(5):914-921. doi:10.1139/x85-147

Fasth BG, Harmon ME, Sexton J, White P (2011) Decomposition of fine woody debris in a deciduous forest in North Carolina. J Torrey Bot Soc 138(2):192-206

Fukusawa Y, Osono T, Takeda H (2011) Wood decomposing abilities of diverse lignicolous fungi on nondecayed and decayed beech wood. Mycologia 103(474-482)

Fukushima RS, Hatfield RD (2004) Comparison of the acetyl bromide spectrophotometric method with other analytical lignin methods for determining lignin concentration in 
forage samples. Journal of agricultural and food chemistry 52, 3713-3720. doi:10.1021/jf0354971

Garrett LDM, Davis M, Oliver G (2007) Decomposition of coarse woody debris and methods for determining decay rates. N Z J For Sci 37:227-240

Gaudinski JB, Trumbore SE, Davidson EA, Zheng SH (2000) Soil carbon cycling in a temperate forest: radiocarbonbased estimates of residence times, sequestration rates and partitioning of fluxes. Biogeochemistry 51(1):33-69. doi:10.1023/a:1006301010014

Harmon ME, Sexton J (1996) Guidelines for measurements of woody detritus in forst ecosystems. US LTER Network, Seattle

Harmon ME, Franklin JF, Swanson FJ, Sollins P, Gregory SV, Lattin JD, Anderson NH, Cline SP, Aumen NG, Sedell JR, Lienkaemper GW, Cromack K, Cummins KW (1986) Ecology of coarse woody debris in temperate ecosystems. Adv Ecol Res 15:133-302. doi:10.1016/s0065-2504(08)60121-x

Johnson DB, Moore WF, Zank LC (1961) The spectrophotometric determination of lignin in small wood samples. TAPPI 44, 793-798

Kaarik AA (1974) Decomposition of wood. In: Dickinson CH, Pugh GJF (eds) Biology of plant litter decomposition. Academic, London, pp 129-174

Kirk TK, Highley TL (1973) Quantitative changes in structural components of conifer woods during decay by white- and brown-rot fungi. Phytopathology 63, 1338-1342.

Laiho R, Prescott CE (2004) Decay and nutrient dynamics of coarse woody debris in northern coniferous forests: a synthesis. Can J For Res-Rev Can Rech For 34(4):763-777. doi:10.1139/x03-241

Lang GE, Cronan CS, Reiners WA (1981) Organic-matter and major elements of the forest floors and soils in subalpine balsam fir forests. Can J For Res-Rev Can Rech For 11 (2):388-399

Liu WH, Bryant DM, Hutyra LR, Saleska SR, Hammond-Pyle E, Curran D, Wofsy SC (2006) Woody debris contribution to the carbon budget of selectively logged and maturing mid-latitude forests. Oecologia 148(1):108-117. doi:10.1007/s00442-006-0356-9

Mackensen J, Bauhus J, Webber E (2003) Decomposition rates of coarse woody debris - a review with particular emphasis on Australian tree species. Aust J Bot 51(1):27-37. doi:10.1071/bt02014

Mattson KG, Swank WT, Waide JB (1987) Decomposition of woody debris in a regenerating, clear-cut forest in the southern appalachians. Can J For Res-Rev Can Rech For 17(7):712-721. doi:10.1139/x87-114

McCarthy BC, Bailey RR (1994) Distribution and abundance of coarse woody debris in a managed forest landscape of the Central Appalachians. Can J For Res-Rev Can Rech For 24 (7):1317-1329

Melillo JM, Steudler PA, Aber JD, Newkirk K, Lux H, Bowles FP, Catricala C, Magill A, Ahrens T, Morrisseau S (2002) Soil warming and carbon-cycle feedbacks to the climate system. Science 298(5601):2173-2176. doi:10.1126/ science. 1074153

Melillo JM, Kicklighter DW, Tian H, Butler S (2010) Fertilizing change: carbon-nitrogen interactions and carbon storage in land ecosystems. In: Hillel D, Rosenzweig C (eds) Handbook of Climate Change and Agroecosystems: impacts, adaptation and mitigation. Imperial College Press, London, pp 21-36
Moore TR, Trofymow JA, Taylor B, Prescott C, Camire C, Duschene L, Fyles J, Kozak L, Kranabetter M, Morrison I, Siltanen M, Smith S, Titus B, Visser S, Wein R, Zoltai S (1999) Litter decomposition rates in Canadian forests. Glob Chang Biol 5(1):75-82. doi:10.1046/j.1365-2486.1998.00224.x

Muller-Using S, Bartsch N (2009) Decay dynamic of coarse and fine woody debris of a beech (Fagus sylvatica L.) forest in Central Germany. Eur J For Res 128(3):287-296. doi:10.1007/s10342-009-0264-8

Okino EYA, Santana MAE, Resck IS, Alves M, Falcomer VAS, da Cunha JBM, dos Santos PHD (2008) Liquid chromatography and solid state CP/MAS C-13 NMR techniques for chemical compound characterizations of cypress wood Cupressus glauca Lam. exposed to brown- and white-rot fungi. Carbohydr Polym 73(1):164-172. doi:10.1016/j. carbpol.2007.11.019

Olson JS (1963) Energy storage and the balance of producers and decomposers in ecological system. Ecology 44, 322331

Onega TL, Eickmeier WG (1991) Woody detritus inputs and decomposition kinetics in a southern temperate deciduous forest. Bull Torrey Bot Club 118(1):52-57. doi:10.2307/2996975

Orwig DA, Foster DR (1998) Forest response to the introduced hemlock woolly adelgid in southern New England, USA. J Torrey Bot Soc 125(1):60-73. doi:10.2307/2997232

Ostle NJ, Smith P, Fisher R, Woodward FI, Fisher JB, Smith JU, Galbraith D, Levy P, Meir P, McNamara NP, Bardgett RD (2009) Integrating plant-soil interactions into global carbon cycle models. J Ecol 97(5):851-863. doi:10.1111/j.13652745.2009.01547.x

Pettersen RC (1984) The chemical composition of wood. In: Rowell RM (ed) The chemistry of soil wood. Advances in chemistry, vol 207. American Chemical Society, Washington, D.C

Preston CM, Trofymow JA, Niu J, Fyfe CA (1998) (13) CPMAS-NMR spectroscopy and chemical analysis of coarse woody debris in coastal forests of Vancouver Island. For Ecol Manage 111(1):51-68. doi:10.1016/s0378-1127 (98)00307-7

Scheffer TC, Cowling EB (1966) Natural resistance of wood to microbial deterioration. Ann Rev Phytophathol 4:147-170

Swift MJ, Heal OW, Anderson JM (1979) Decomposition in terrestrial ecosystems. University of California Press, Berkeley

Tritton LM (1980) Dead wood in the northern hardwood forest ecosystem. Dissertation, Yale University

Tuomi M, Laiho R, Repo A, Liski J (2011) Wood decomposition model for boreal forests. Ecol Model 222(3):709-718. doi:10.1016/j.ecolmodel.2010.10.025

Vávřová P, Penttilä T, Laiho R (2009) Decomposition of Scots pine fine woody debris in boreal conditions: implications for estimating carbon pools and fluxes. For Ecol Manage 257(2):401-412. doi:10.1016/j. foreco.2008.09.017

Wang CK, Bond-Lamberty B, Gower ST (2002) Environmental controls on carbon dioxide flux from black spruce coarse woody debris. Oecologia 132(3):374-381. doi:10.1007/ s00442-002-0987-4

Worrall JJ, Anagnost SE, Zabel RA (1997) Comparison of wood decay among diverse lignicolous fungi. Mycologia 89 (2):199-219. doi:10.2307/3761073 
Wu JB, Zhang XJ, Wang HL, Sun JW, Guan DX (2010) Respiration of downed logs in an old-growth temperate forest in north-eastern China. Scand J For Res 25(6):500-506. doi:10.1080/02827581.2010.524166

Yang FF, Li YL, Zhou GY, Wenigmann KO, Zhang DQ, Wenigmann M, Liu SZ, Zhang QM (2010) Dynamics of coarse woody debris and decomposition rates in an old-growth forest in lower tropical China. For Ecol Manage 259(8):1666-1672. doi:10.1016/j. foreco.2010.01.046

Yin XW (1999) The decay of forest woody debris: numerical modeling and implications based on some 300 data cases from North America. Oecologia 121(1):81-98. doi:10.1007/s004420050909 